\title{
Genetic analysis reveals that PAX6 is required for normal transcription of pancreatic hormone genes and islet development
}

\author{
Maike Sander, ${ }^{1}$ Annette Neubüser, ${ }^{3}$ Julie Kalamaras, ${ }^{1}$ Hooi C. Ee, ${ }^{1}$ Gail R. Martin, ${ }^{3}$ and \\ Michael S. German ${ }^{1,2,4}$ \\ ${ }^{1}$ Hormone Research Institute, ${ }^{2}$ Department of Medicine, ${ }^{3}$ Department of Anatomy and Program in Developmental Biology, \\ University of California, San Francisco, California 94143-0534 USA
}

\begin{abstract}
We present genetic and biochemical evidence that PAX6 is a key regulator of pancreatic islet hormone gene transcription and is required for normal islet development. In embryos homozygous for a mutant allele of the Pax6 gene, Small eye (Sey ${ }^{\mathrm{Neu}}$ ), the numbers of all four types of endocrine cells in the pancreas are decreased significantly, and islet morphology is abnormal. In the remaining islet cells, hormone production, particularly glucagon production, is markedly reduced because of decreased gene transcription. These effects appear to result from a lack of PAX6 protein in the mutant embryos. Biochemical studies identify wild-type PAX6 protein as the transcription factor that binds to a common element in the glucagon, insulin, and somatostatin promoters, and show that PAX6 transactivates the glucagon and insulin promoters.
\end{abstract}

[Key Words: Glucagon; insulin; islet; pancreas development; PAX6; transcription]

Received March 31, 1997; revised version accepted May 21, 1997.

The pancreatic islets of Langerhans are specialized endocrine micro-organs composed of four different cell types, $\alpha, \beta, \delta$, and PP cells, which produce the hormones glucagon, insulin, somatostatin, and pancreatic polypeptide (PP), respectively. These hormones are key regulators of nutrient metabolism. The islets are distributed throughout exocrine tissue that produces digestive enzymes and accounts for most of the mass of the pancreas. Because diabetes mellitus, caused in part by inappropriate regulation of insulin production, is a significant health problem, the transcription factors that regulate the expression of insulin and other islet hormone genes have been intensively studied, and much is known about the mechanism by which each islet hormone gene is activated in the appropriate islet cell type (for review, see Sander and German 1997).

The prevailing view is that the specificity of islet hormone gene expression depends on the interaction of multiple transcription factors, none of which are absolutely cell type-specific. One such transcription factor is PDX1, which is produced in both $\beta$ and $\delta$ cells in the adult islet, as well as in a subset of gut epithelial cells (Leonard et al. 1993; Miller et al. 1994; Guz et al. 1995). PDX1 by itself binds to and can weakly transactivate the insulin gene promoter (Ohlsson et al. 1993). However, a much stron-

${ }^{4}$ Corresponding author.

E-MAIL german@cgl.ucsf.edu; FAX (415) 731-3612. ger activation is produced by PDX1 in combination with a heterodimer of the transcription factors E47 and BETA2/NeuroD, which binds to an adjacent site on the insulin promoter (Peers et al. 1994). E47 is widely expressed, whereas BETA2/NeuroD expression is restricted to islet cells and central nervous system (CNS) neurons (Naya et al. 1995). In addition, an unidentified transcription factor(s) that binds to a DNA sequence common to the insulin, glucagon, and somatostatin gene promoters, the pancreatic islet cell enhancer sequence (PISCES), has been detected in islet cell lines, but not in cell lines derived from the exocrine pancreas. Because in vitro mutation studies have demonstrated that the PISCES element is important for the activity of each of the three hormone gene promoters, it has been suggested that the PISCES-binding factor(s) are a key component of the transcription complexes involved in their transactivation (Knepel et al. 1991). However, it is unclear whether the current model accurately describes the mechanism of islet hormone gene regulation in vivo, as it is based on results obtained from studies using islet tumor cell lines.

As of yet, genetic studies that could potentially address the mechanism of islet hormone gene regulation have not been informative, because so far all null mutations in genes that encode transcription factors presumed to regulate islet hormone gene expression prevent pancreas development. For example, homozygosity for a 
null mutation in $P d x 1$, a gene expressed normally in all cells of the pancreatic bud (Guz et al. 1995), causes an arrest of pancreatic growth and differentiation at the bud stage (Ahlgren et al. 1996; Offield et al. 1996). Another transcription factor, ISL1, which is produced in all islet cells and can transactivate the glucagon promoter (Wang and Drucker 1995|, also appears to be required for pancreas development and islet cell differentiation. Although embryos homozygous for a null allele of Isl1 die at embryonic day 9.5 (E9.5), it has been shown that cells producing glucagon, insulin, and somatostatin form in explants from heterozygotes, whereas no pancreatic endocrine cells form in explants from mutant homozygous embryos (Ahlgren et al. 1997).

These and other data support the general idea that transcription factors that regulate gene expression specific to a particular tissue are also required for the development of that tissue. Several examples of such transcription factors can be found among the members of the Pax family of vertebrate genes, all of which contain a conserved sequence motif, the paired box, which encodes a DNA-binding domain (Mansouri et al. 1996). PAX8 regulates expression of the thyroperoxidase and the thyroglobulin genes that are expressed in mature thyroid follicular cells (Zannini et al. 1992), and a null mutation in the Pax8 gene causes a defect in thyroid development (Mansouri et al. 1996). Likewise, a role for Pax5 has been demonstrated in the transcriptional regulation of lymphocytic B cell-specific genes (Kozmik et al. 1992; Singh and Birshtein 1993), and in the differentiation of B cells (Urbanek et al. 1994). PAX6, which in addition to the paired domain also contains a homeodomain, contributes to transcriptional activation and lensspecific expression of the crystallin genes (Cvekl et al. 1995a,b|, and mutations in Pax6 cause disruptions in eye development in a number of different organisms. Mutant alleles of Pax6 are semi-dominant in mammals and cause a reduction in eye size and iris hypoplasia in mice and rats (Hogan et al. 1988; Hill et al. 1991; Matsuo et al.
1993), aniridia and Peter's anomaly in humans (Jordan et al. 1992; Glaser et al. 1994), and a failure of eye development in Drosophila (Quiring et al. 1994). In mice, homozygosity for the Pax6 mutation Small eye (Sey) causes lethality at birth, presumably as a consequence of brain abnormalities and a complete disruption of eye and nasal development (Hogan et al. 1988; Schmahl et al. 1993; Stoykova et al. 1996). Although a number of distinct mutant alleles of Sey have been described, mice carrying these different $P a x 6$ mutations are phenotypically indistinguishable (Hill and Van Heyningen 1992).

Two Pax genes, Pax 4 and Pax6, are expressed in the pancreas. Mice homozygous for a null allele of $\mathrm{Pax} 4$ lack mature $\beta$ and $\delta$ cells, and $\alpha$ cells are present in higher numbers, indicating that $P a \times 4$ is required for normal development of pancreatic endocrine cells (Sosa-Pineda et al. 1997). Pax6 is expressed in the developing pancreas, and also in insulin- and glucagon-producing islet tumor cell lines, but not in exocrine cell lines (Walther and Gruss 1991; Turque et al. 1994). In this study, we have explored $\mathrm{Pax} 6$ function in the pancreas by analyzing embryos homozygous for the Sey ${ }^{\mathrm{Neu}}$ mutation. Our analysis identifies PAX6 as the factor that binds to the PISCES element, and provides genetic evidence that $\operatorname{Pax} 6$ is required for normal islet hormone gene transcription, islet morphogenesis, and the formation of normal numbers of all four islet cell types.

\section{Results}

The numbers of islet hormone-producing cells are reduced in the pancreas of Sey ${ }^{\mathrm{Neu}}$ mutant homozygotes

To determine when Pax6 is expressed in the developing pancreas, we performed an immunohistochemistical analysis using an anti-PAX6-antiserum (Fig. 1) and an RNA in situ hybridization analysis using an anti-sense Pax6 probe (data not shown) on sections of mouse em-
E9.0

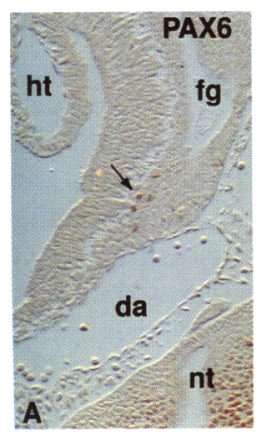

E9.5

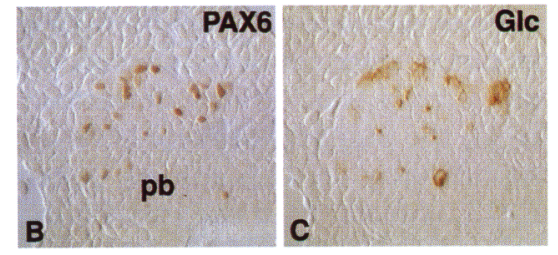

E15.5

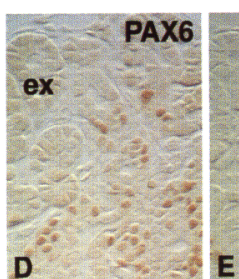

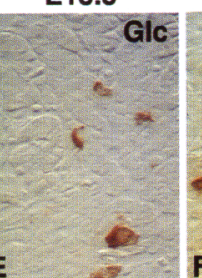

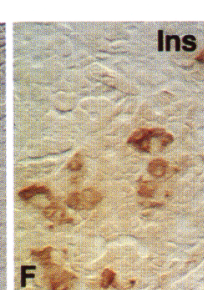

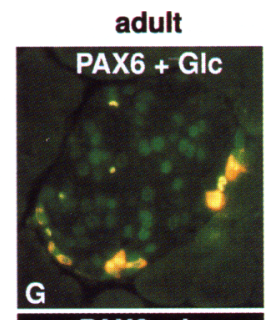

PAX6 + Ins

Figure 1. Pax6 protein marks cells of the endocrine lineage in the embryonic and adult mouse pancreas. Immunohistochemical staining for PAX6 $(A, B, D)$, glucagon (Glc) $(C, E)$, and insulin (Ins) $(F)$ in the developing and adult pancreas. $(A) \mathrm{A}$ mouse embryo at E9.0. The arrow points to a PAX6-positive cell in the foregut endoderm (fg). Note also the PAX6-producing cells in the neural tube (nt). Near-adjacent sections of the pancreatic bud $(\mathrm{pb})(B, C)$ at E9.5; $(D, E, F)$ the pancreas at E15.5. Note the exocrine acini (ex) in the upper left corner. $(G, H)$ Double immunofluorescence staining of adult pancreas sections with anti-PAX6 and anti-glucagon antisera or anti-PAX6 and anti-insulin antisera, as indicated. PAX6 (fluorescein label, green stain), which is localized to the nucleus, is detectable in all islet cells. Glucagon (in $G$ ) or insulin (in $H$ ) (rhodamine label; orange stain) are detectable in the cytoplasm of a subset of the PAX6-positive cells. (da) Dorsal aorta; (ht) heart. 
bryos at various stages of development. In the mouse, the pancreas first appears on E9.5, as a dorsal bulge in the endoderm at the junction of the foregut and midgut. Glucagon-producing cells are detectable at the time that the pancreatic bud becomes apparent ( E9.5). The following day $(-$ E10.5), insulin-producing cells can be detected, and in some cells, co-expression of glucagon and insulin is observed. Cells that produce somatostatin appear at E15, and PP-producing cells can be detected at E18.5, shortly before birth. Exocrine cells become morphologically and biochemically distinct from the endocrine cells at -E14.5 (Slack 1995).

Cells in the fore/midgut endoderm did not stain with an anti-PAX6 antiserum at E8.5, but by E9.0, PAX6-producing cells were detected in a subset of fore/midgut cells (Fig. 1A; data not shown). At E9.5, PAX6 protein was detected in a few cells in the pancreatic bud, and immunohistochemical staining of adjacent sections with an anti-glucagon antiserum suggested that cells producing PAX6 were also producing glucagon (Fig. 1B,C). At E15.5, Pax6 mRNA and PAX6 protein were detected in many cells in the developing pancreas, but were not detected in cells in the nascent acini of the exocrine pancreas (Fig. 1D; data not shown). Immunohistochemical staining of adjacent sections suggested that the cells that stained with the anti-PAX6 antiserum were also producing either glucagon or insulin at this stage (Fig. IE,F), and therefore were endocrine cells. Likewise, in the adult pancreas, double immunofluorescence staining for PAX6 and glucagon demonstrated that these two proteins were expressed in the same cells (Fig. 1G). Similar assays indicated that individual islet cells produced both PAX6 and insulin (Fig. 1H), PAX6 and somatostatin, or PAX6 and PP (data not shown). In this analysis we found that all cells that were producing a pancreatic hormone also contained PAX6 protein in their nuclei. In contrast, no Pax6 mRNA or PAX6 protein was detected in pancreatic exocrine cells (Fig. 1G,H; data not shown). Together, these data show that Pax6 is expressed in the region in which the pancreatic bud will form, and at the earliest stages of pancreas differentiation in cells that are producing glucagon. At later stages of embryogenesis and in the adult, when all four types of endocrine cells are present, it is expressed throughout the endocrine pancreas.

These data raised the possibility that $\operatorname{Pax} 6$ may have a role in islet cell development and differentiation. To explore this hypothesis, we examined the pancreas in embryos homozygous for the Pax6 mutant allele, Sey ${ }^{\mathrm{Neu}}$. This allele contains a point mutation in a splice donor site 3 ' of the homeobox, which results in incorrect splicing. The mRNA produced contains 116 nucleotides of intronic sequence between the homeobox and a downstream sequence that encodes a transcriptional activation domain (Glaser et al. 1994). Because this intronic sequence contains an in-frame stop codon, the Sey ${ }^{\mathrm{Neu}}$ allele encodes a protein that lacks the carboxy-terminal 115 amino acids of the normal PAX6 protein, including the transcriptional activation domain.

At E18.5, just before birth, the pancreas of mutant ho- mozygotes was found to be normal in size and weight (data not shown), and appeared grossly similar in histological section to the pancreas of their heterozygous and wild-type littermates. However, when sections of pancreas from mutant homozygotes were assayed by antibody staining, a marked reduction in glucagon-, insulin-, somatostatin-, and PP-producing cells was detected (Fig. 2A-D; data not shown). This was particularly evident from the observation that glucagon-producing cells were not detected in several sections of mutant homozygous pancreas, but were always detected in sections of mutant heterozygous or wild-type pancreas. To quantify these differences, we serially sectioned whole E18.5-pancreata and determined the number of insulin- and glucagonpositive cells in approximately every twentieth section ( $n=8$ sections per pancreas). The data from this analysis showed that the mean number of hormone-expressing cells per section was three to fourfold lower in the mutant homozygotes than in their heterozygous or wildtype littermates (Table 1A).

The observed reduction in endocrine cell numbers in the mutant homozygotes was not attributable to an inability to detect low levels of hormone in a subset of endocrine cells, because all cells in the islet clusters were stained with one of the antisera specific for islet hormones. In addition, staining with antisera for other $\beta$-cell markers, NKX6.1 (Rudnick et al. 1994; Jensen et al. 1996) and PDX1, confirmed that the number of $\beta$ cells was reduced.

In addition to their reduced number, hormone-producing cells were found to be abnormally distributed in the mutant homozygous pancreas. In the normal embryo the endocrine cells are initially found singly or in small clusters, but at $\sim$ E18.5, endocrine cell aggregates begin to develop the architecture of mature islets (Slack 1995), in which a core of $\beta$ cells is surrounded by a mantle of $\alpha$ cells, $\delta$ cells, and PP-producing cells (Fig. 2A; data not shown). In the mutant homozygotes, the number of developing islets appeared to be normal, but the hormone-producing cells were found to be scattered within the nascent islets (Fig. 2B). Collectively, these findings suggest a role for PAX6 in islet cell development and islet morphogenesis.

To determine when these defects first appear, we examined the pancreas from homozygous mutant embryos at earlier stages of development. At E12.5, when both $\alpha$ and $\beta$ cells were readily detectable in the normal pancreas, the numbers of these cells appeared to be reduced significantly in the mutant pancreas (Fig. 2E-H). At E10.5, a decrease in the number of glucagon-expressing cells was also evident (data not shown). Insulin-expressing cells were observed in the mutant pancreas at E10.5, but we were unable to determine whether their number was reduced because they are just becoming detectable at this stage and their numbers are small, even in wildtype embryos. For the same reason we were unable to determine whether the number of glucagon-expressing cells in the mutant homozygotes was reduced at E9.5. We conclude that the Sey ${ }^{\mathrm{Neu}}$ mutation does not cause a delay in the onset of glucagon and insulin expression in the pancreatic bud, but results in a reduction in the num- 


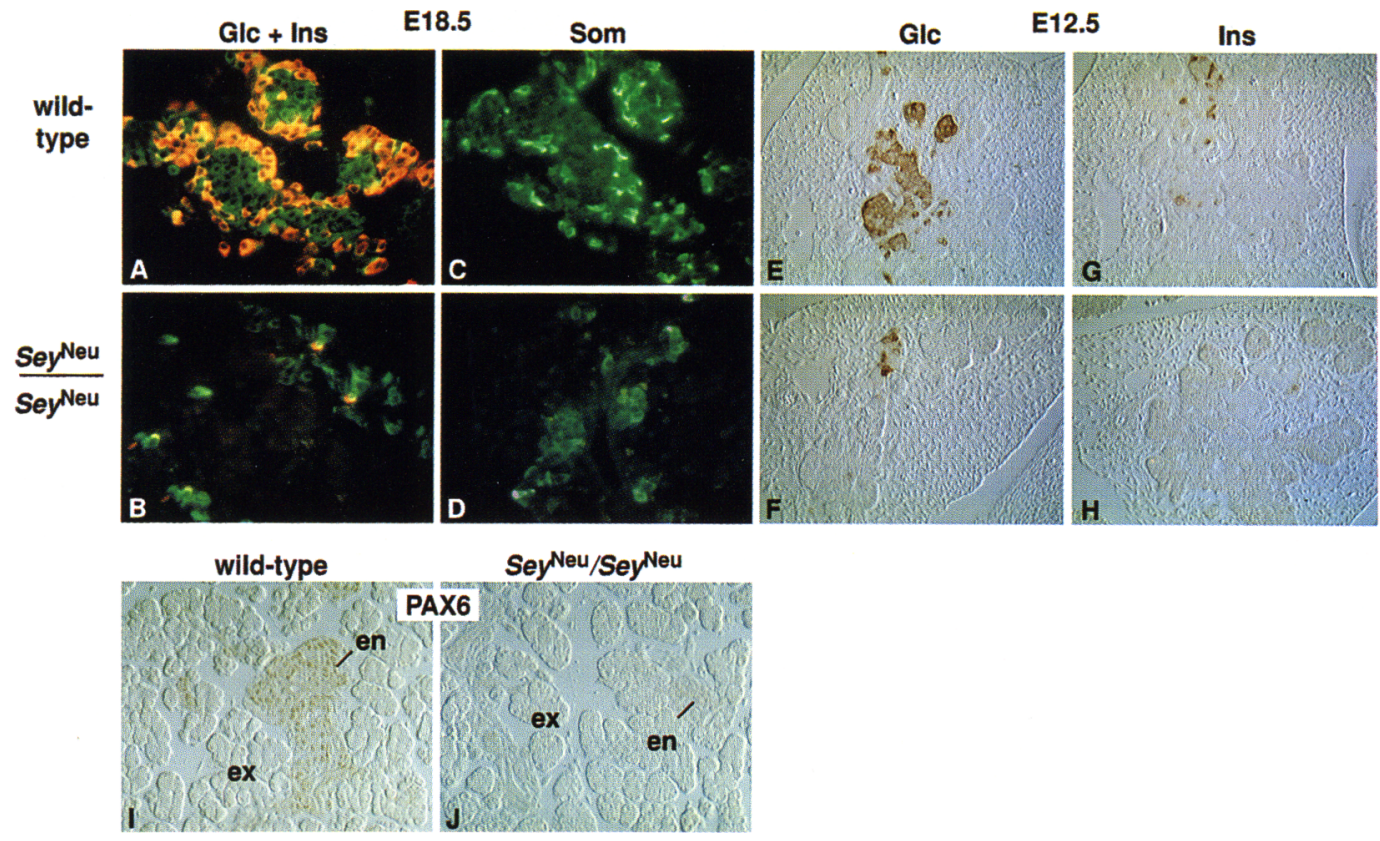

Figure 2. Hormone-producing islet cells are reduced in number and PAX6 is not detected in the pancreas of Sey ${ }^{\text {Neu }}$ mutant homozygotes. $(A-H)$ Detection of insulin (Ins), glucagon (Glc), and somatostatin (Som) in wild-type and mutant homozygous pancreata, as indicated. $(A, B)$ Pancreatic sections from E18.5 embryos stained with anti-glucagon (rhodamine label) and anti-insulin (fluorescein label) antisera; $(C, D)$ anti-somatostatin (fluorescein label) antiserum. Sections of E12.5 embryos stained with anti-glucagon $(E, F)$ and anti-insulin antisera $(G, H)$. $(I, J)$ Immunohistochemical analysis of PAX6 in wild-type $(I)$ and mutant homozygous $(J)$ E18.5 pancreas. Note PAX6-staining in endocrine (en) but not exocrine (ex) cells of the wild-type pancreas.

ber of cells producing these hormones by as early as E10.5.

To determine whether the $S e y^{\mathrm{Neu}}$ mutation affects the level of PAX6 protein, we assayed for PAX6 protein by immunohistochemical staining of pancreas sections at various stages of development. Although PAX6-producing cells were detected readily in wild-type or mutant heterozygous pancreas, none were observed in the mutant homozygous pancreas at stages from E10.5 to E18.5 (Fig. 2I,J; data not shown). Interestingly, immunoreactivity with anti-PAX6 antiserum was detected at low levels in the neural tube of the mutant homozygotes (data not shown).

\section{PAX6 regulates glucagon and insulin production}

We next sought to determine the extent to which loss of Pax6 function attributable to the Sey ${ }^{\mathrm{Neu}}$ mutation affects hormone production. To quantify the amount of hormones produced in the pancreas, we prepared extracts of whole pancreas from E18.5-mutant homozygotes and their littermates. The amount of total protein and also of amylase, which is produced exclusively by the exocrine cells, was the same in each pancreas assayed (Table $1 \mathrm{~B}$; data not shown). In contrast, the amount of glucagon in the pancreas of mutant homozygotes was reduced to only $2.6 \%$ of the amount in the wild-type pancreas. The amount of insulin protein and of insulin mRNA were also found to be reduced dramatically in mutant homozygotes $(13 \%$ and $8 \%$ of the amounts in wild-type pancreas, respectively) (Table 1B). Therefore, the data shown in Table 1 demonstrate that the reduction in hormone and hormone mRNA levels is greater than the reduction in the number of hormoneproducing cells in Sey ${ }^{\mathrm{Neu}}$ mutant homozygotes, suggesting that the lack of PAX6 protein in the mutant homozygous pancreas affects hormone gene transcription in those islet cells that are present.

\section{PAX6 binds to glucagon, insulin, and somatostatin gene regulatory elements}

A possible mechanism by which PAX6 might regulate hormone gene transcription became evident when we found a PAX6-binding site in an islet-specific enhancer of the glucagon promoter. Specifically, a sequence identical to that of the core sequence of the PAX6 paired domain consensus recognition site (Epstein et al. 1994) was found at position -262 to $-248 \mathrm{bp}$ relative to the start site of transcription of the rat glucagon gene (Fig. $3 \mathrm{~A})$, and is also conserved in the human glucagon promoter (White and Saunders 1986). This sequence is part of the A site of the glucagon G3 promoter element, which is similar to sequences also found in the rodent insulin I and insulin II and somatostatin promoters, and therefore has been referred to as the pancreatic islet cell 
Table 1. Number of hormone-expressing cells and quantification of hormone and hormone mRNA levels and amylase activity in pancreata from 18.5 embryos carrying the Sey ${ }^{\text {Neu }}$ allele and their wild-type littermates

\begin{tabular}{|c|c|c|c|}
\hline \multicolumn{4}{|c|}{ A. Numbers of hormone-producing cells } \\
\hline Cell no./section ${ }^{a}$ & $+1+$ & $\begin{array}{l}\text { Sey } \\
\text { (\% of wild type) }\end{array}$ & $\begin{array}{l}S e y^{\mathrm{Neu}} / \mathrm{Sey} \mathrm{N}^{\mathrm{Neu}} \\
(\% \text { of wild type })\end{array}$ \\
\hline Glucagon-positive cells & $155 \pm 29$ & $179 \pm 32(115 \%)$ & $41 \pm 19(27 \%)$ \\
\hline Insulin-positive cells & $341 \pm 26$ & $317 \pm 67(93 \%)$ & $105 \pm 30(31 \%)$ \\
\hline
\end{tabular}

\section{B. Protein and mRNA levels}

\begin{tabular}{|c|c|c|c|}
\hline $\begin{array}{l}\text { Hormone concentration, } \\
\text { hormone gene mRNA levels, } \\
\text { or enzymatic activity }\end{array}$ & $+1+$ & $\begin{array}{c}\mathrm{Sey}^{\mathrm{Neu}} /+ \\
(\% \text { of wild type })\end{array}$ & $\begin{array}{l}S e y^{\mathrm{Neu}} / \mathrm{Se} y^{\mathrm{Neu}} \\
(\% \text { of wild type) }\end{array}$ \\
\hline Glucagon (ng/mg of protein) & $\begin{array}{l}527 \pm 62.8 \\
(n=11)\end{array}$ & $\begin{array}{c}522 \pm 35.0(99 \%) \\
(n=27)\end{array}$ & $\begin{array}{c}13.9 \pm 1.45(2.6 \%) \\
(n=10)\end{array}$ \\
\hline Insulin $(\mu \mathrm{g} / \mathrm{mg}$ of protein) & $\begin{array}{r}12.2 \pm 1.3 \\
(n=11)\end{array}$ & $\begin{array}{c}9.1 \pm 0.92(75 \%) \\
(n=27)\end{array}$ & $\begin{array}{c}1.6 \pm 0.08(13 \%) \\
(n=10)\end{array}$ \\
\hline Amylase (U/mg of protein) & $\begin{array}{c}74.4 \pm 4.0 \\
(n=6)\end{array}$ & & $\begin{array}{c}74.5 \pm 9.7(100 \%) \\
(n=6)\end{array}$ \\
\hline $\begin{array}{l}\text { Insulin mRNA (copies/ug } \\
\text { of pancreatic RNA) }\end{array}$ & $\begin{array}{c}57.3 \times 10^{6} \pm 12.5 \times 10^{6}(8 \%) \\
(n=6)\end{array}$ & $\begin{array}{c}34.1 \times 10^{6} \pm 5.7 \times 10^{6}(60 \%) \\
(n=14)\end{array}$ & $\begin{array}{c}4.58 \times 10^{6} \pm 0.94 \times 10^{6} \\
(n=6)\end{array}$ \\
\hline
\end{tabular}

The average number of glucagon- or insulin-positive cells per section (as detected by immunohistochemical staining) was determined by counting stained cells in eight sections from an individual pancreas (approximately every twentieth section). The numbers shown represent the mean number \pm S.E. of the mean (S.E.M.) of hormone-positive cells per section from four independent pancreata.

bHormone concentrations and amylase activity were determined in protein extracts from individual pancreata. Insulin mRNA levels were determined by the branched DNA assay (see Materials and Methods). The values shown represent the mean \pm S.E.M. value from the number of samples assayed $(n)$.

enhancer sequence (PISCES) (Knepel et al. 1991) (Fig. 3A).

To determine whether PAX6 binds to the glucagon promoter, we performed electrophoretic mobility shift assays (EMSAs) with nuclear extracts of $\alpha$ TC1.9 (a glucagon-producing cell line), $\beta$ TC4 (an insulin-producing cell line), and 3T3 cells (a fibroblast cell line that does not produce any pancreatic hormones) in the presence and absence of an anti-PAX6 antiserum raised against the paired domain (Turque et al. 1994), which is the major DNA-binding domain of PAX6 (Epstein et al. 1994). Using a ${ }^{32} \mathrm{P}$-labeled 35 -bp oligonucleotide spanning the rat glucagon G3 promoter element (-265 to -231 bp; G3) as a probe, a retarded complex was detected in nuclear extracts from hormone-producing cells but not from fibroblasts (Fig. 3B). Similar results were obtained using a probe containing only the A site of the G3 element (-265 to -245 bp; G3A probe) (data not shown). However, when anti-PAX6 antiserum was added to the EMSA reaction, no islet cell-specific complex could be detected with either the G3 or G3A probe (Fig. 3B).

We next sought to confirm that the observed inhibition of complex formation was attributable to binding of the anti-PAX6 antiserum to PAX6 and not to other PAX proteins potentially present in the nuclear extracts (Fig. 3C,D). The anti-PAX6 antiserum that we used was raised against the paired domain, which is relatively well conserved among PAX proteins and is most similar to the paired domain in PAX4, which is also produced in the pancreas (Walther et al. 1991; Sosa-Pineda et al. 1997).
Therefore, we assayed the ability of this antibody to bind to glutathione-S-transferase (GST) fusion proteins containing the paired domain of either PAX6 or PAX4. Western blot analysis showed that the anti-PAX6 antiserum binds to PAX6-GST but not PAX4 -GST fusion protein, or GST alone (Fig. 3D). Furthermore, we found that PAX6-GST but not PAX4-GST can bind the G3 probe in an EMSA (Fig. 3C).

To determine whether PAX6 is sufficient to produce the islet cell-specific complex that binds to the G3 element, we prepared full-length in vitro translated PAX6 protein and performed an EMSA with the G3 probe. In this assay, a complex with mobility similar to that of the islet cell-specific complex was detected (Fig. 3E), providing evidence that PAX6 alone is the islet cell-specific G3-binding factor (PISCES-binding factor). Together with our finding that glucagon production appears to be reduced in those glucagon-producing cells that are present in Sey ${ }^{\mathrm{Neu}}$ mutant homozygotes, these data suggest strongly that PAX6 contributes to glucagon expression in vivo.

To characterize PAX6-binding specificity, we performed EMSAs in which a variety of unlabeled oligonucleotides were tested for their ability to compete with the G3 element for binding to PAX6 in a nuclear extract of $\alpha \mathrm{TC} 1.9$ cells (Fig. 3F). In control experiments, we found that the PAX6-G3 complex was not detectable in the presence of an excess of unlabeled G3 oligonucleotide. Similar results were obtained when the competitor was a G3 oligonucleotide containing a mutation in the $B$ 


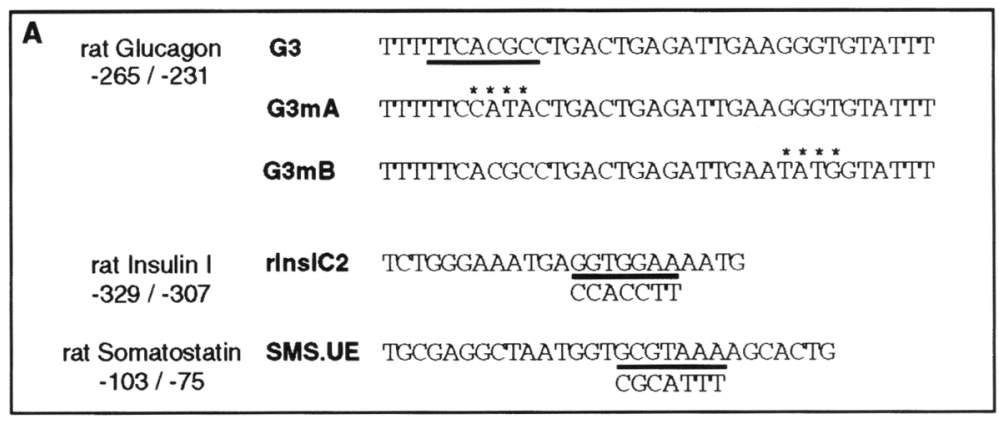
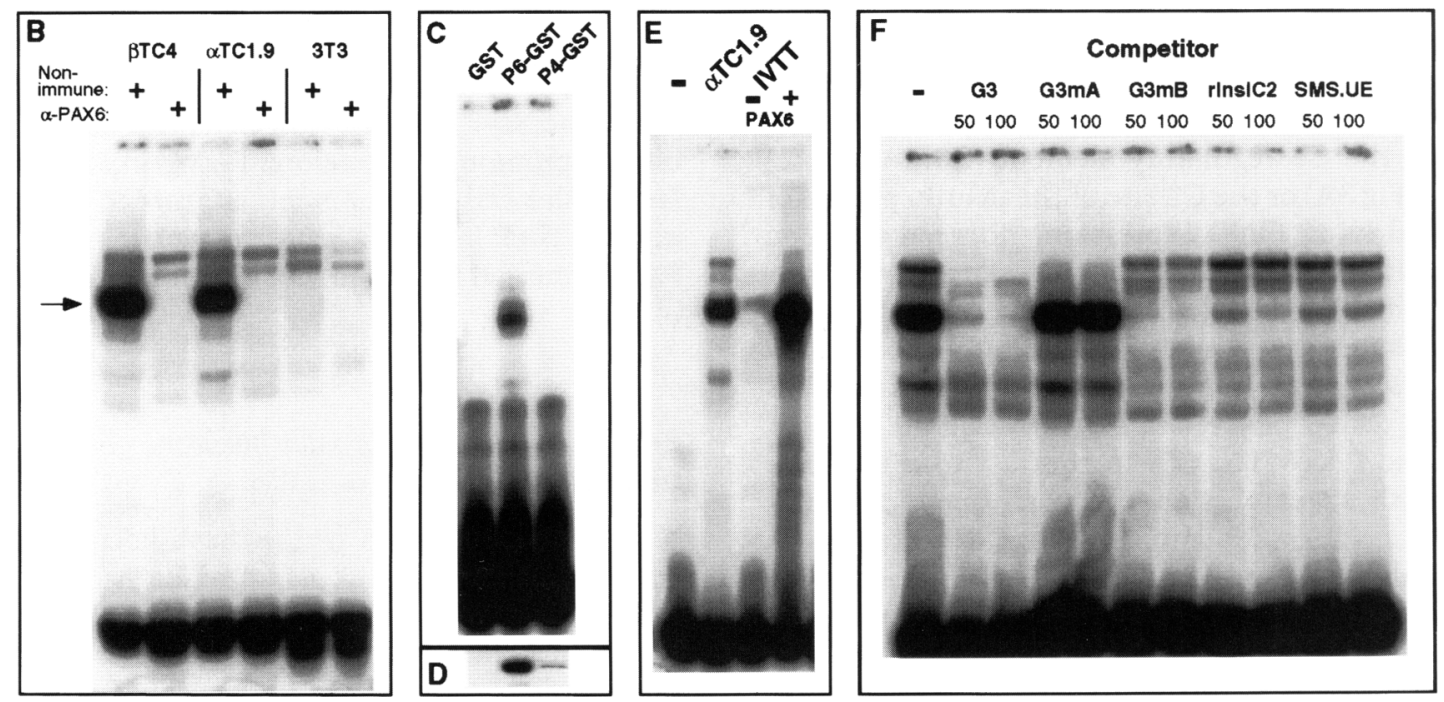

Figure 3. Pax6 binds to islet hormone gene promoters. $|A|$ Sequences of the oligonucleotides used in EMSAs. In the G3 sequence, which is derived from the rat glucagon promoter, the core bases of the PAX6-binding site consensus sequence are underscored (Epstein et al. 1994). In the G3mA and G3mB sequences, the mutated bases are indicated by asterisks. In the rat insulin I and the rat somatostatin promoter sequences, the lines indicate regions in which sequences that are similar to the core bases of the PAX6-binding site consensus sequence are found on the complementary strand. $(B, C, E, F)$ EMSAs using a ${ }^{32}$ P-end-labeled G3 oligomer as a probe. $(B)$ The labeled oligomer was incubated with nuclear extracts from different cell lines $(\alpha \mathrm{TC} 1.9, \beta T C 4$, and NIH3T3), and nonimmune or anti-PAX6 antiserum (1:20 final dilution), as indicated. The arrow indicates the islet-cell-specific complex. (C) The labeled oligomer was incubated with a control GST protein (GST) or a GST fusion protein containing the PAX6 (P6-GST) or the PAX4 (P4-GST) paired domain. (E) Protein produced by in vitro transcription and translation (IVTT) of a vector with (+ PAX6) or without (-PAX6) a cDNA insert that contains the full Pax6-coding sequence. The lane on the left (-) contains free probe; the next lane ( $\alpha \mathrm{TC} 1.9)$, contains nuclear extract from $\alpha$ TC1.9 cells. $|F|$ Unlabeled oligonucleotide competitors in 50- or 100-fold molar excess, as indicated, were added to the EMSA reaction mixture containing a nuclear extract of $\alpha$ TC1.9 cells. $(D)$ The GST fusion proteins used in $C$ were analyzed by Western blotting with the anti-PAX6 antiserum (1:4000 dilution).

site (G3mB; see Fig. 3A), whereas a G3 oligonucleotide containing a mutation in the A site (G3mA; see Fig. 3A) failed to compete for PAX6 binding. These results confirm that PAX6 binds to the A site of the G3 element. Because the islet cell-specific G3-binding complex has been shown also to bind to elements in the rat insulin I and somatostatin promoters (Knepel et al. 1991), we used oligonucleotides from those elements as competitors. We found that the PAX6-G3 complex was not detected when either the insulin C2 element [known previously as the E1 element (German et al. 1995)] or the somatostatin upstream element (UE) were used as competitors (Fig. 3F). These findings suggest strongly that PAX6 binds to the promoter of at least three of the four pancreatic hormone genes.
Wild-type PAX6, but not the protein encoded by the Sey $^{\text {Neu }}$ allele, transactivates the glucagon G3 regulatory element and the insulin promoter

Based on these results, it seemed likely that the reduction in glucagon and insulin production per cell in Sey ${ }^{\text {Neu }}$ mutant embryos is attributable to a failure of the promoters of these genes to be transactivated by PAX6. Although our data suggest that PAX6 protein is not produced in the mutant homozygous pancreas, we cannot exclude the possibility that the mutant PAX6 protein is present at low levels. We therefore sought to determine whether the mutant protein is capable of transactivating the glucagon and insulin promoters using a transfection assay system. Baby hamster kidney (BHK) cells were 
transfected with expression constructs encoding wildtype or Sey ${ }^{\mathrm{Neu}}$ mutant PAX6 protein and a reporter plasmid containing chloramphenicol acetyltransferase (CAT) under the control of either the glucagon G3 regulatory element linked to a minimal thymidine kinase (tk) promoter (G3) or the insulin promoter ( $\mathrm{rInsI} ;-345$ to +1 bp). Previous studies have shown that nuclear extracts from BHK cells do not contain a protein complex with mobility similar to that of the islet-specific G3binding complex (Philippe et al. 1995).

Our results showed that transfection of BHK cells with a construct that produces wild-type PAX6 protein strongly stimulated CAT expression (Fig. 4A,B). Consistent with the observations described above, when mutations within the reporter constructs were made in the G3A site of the G3 regulatory element $(\mathrm{G} 3 \mathrm{~mA}$; for sequence, see Fig $3 \mathrm{~A}$ ) or the $\mathrm{C} 2$ site of the insulin promoter (rInsImC2) driving CAT expression, no reporter gene transactivation occurred in the presence of wild-type PAX6 protein (Fig, 4A,B). Interestingly, transcriptional activation of reporter gene expression by PAX6 was reduced modestly when a mutation was made in the G3B site ( $\mathrm{G} 3 \mathrm{mB}$; for sequence, see Figs. $3 \mathrm{~A}$ and $4 \mathrm{~A}$ ), which does not bind PAX6 (Fig. $3 F$ ). In contrast to the results obtained with an expression construct encoding wildtype PAX6, no transactivation of CAT reporter genes was detected following cotransfection of BHK cells with an expression contruct encoding the Sey ${ }^{\text {Neu }}$ mutant PAX6 protein. Therefore, the protein encoded by the SeyNeu allele apparently is unable to activate transcription of either the glucagon G3 element or the insulin promoter.

\section{Discussion}

We have shown that PAX6 protein is detectable at E9 in cells in the region of the primitive gut that will give rise to the pancreas. At E9.5, PAX6 is detected in the gluca- gon-producing cells of the nascent pancreas, and at later stages of development it is found in all pancreatic endocrine cells. Embryos homozygous for the Sey ${ }^{\mathrm{Neu}}$ mutation in the $P a x 6$ gene, which die at birth, have reduced numbers of all four islet cell types and display abnormal islet morphogenesis. Furthermore, the amounts of insulin, insulin mRNA, and glucagon are decreased markedly in Sey ${ }^{\text {Neu }}$ homozygous embryos. Although some of this decrease is presumably attributable to a reduction in the number of hormone-producing cells, we have also provided evidence that there is a direct effect on hormone gene transcription. We have shown that PAX6 binds to crucial elements of the glucagon, insulin, and somatostatin gene promoters, and that PAX6, but not the product of the Sey ${ }^{\text {Neu }}$ allele, transactivates the glucagon and insulin promoters. Therefore, PAX6, in addition to regulating islet cell development, appears to be required for normal islet hormone gene transcription, and loss of PAX6 function results in insulin and glucagon deficiency in vivo.

\section{PAX6 as a regulator of islet hormone gene transcription}

Multiple transcription factors have been found to activate the insulin and glucagon promoters in vitro, but our data show that loss of function of a single transcription factor substantially reduces the ability of pancreatic hormone gene transcription complexes to function in vivo. This might be explained by reduced expression levels in mutant homozygotes of other transcription factors that normally participate in the activation of the hormone genes. However, this seems unlikely as we found no reduction in the pancreas of Sey ${ }^{\mathrm{Neu}}$ mutant homozygotes of the expression levels of $N k x 6.1$ or $P d x 1$ (data not shown), two transcription factors likely to play a role in the regulation of $\beta$-cell gene expression. Therefore it
Figure 4. Wild-type PAX6 protein but not the protein encoded by the Sey ${ }^{\mathrm{Neu}}$ mutant allele activates glucagon and insulin transcription. BHK21 cells were cotransfected with a CAT reporter gene under control of a minimal tymidine kinase $(\mathrm{t} k)$ promoter and a G3 enhancer $(A)$ or -345 to $+1 \mathrm{bp}$ of the rat insulin I (rInsI) promoter $(B)$, and with an expression vector containing the full-length coding sequence of the Pax6 wild-type or the Sey ${ }^{\mathrm{Neu}}$ mutant allele, or with the vector alone (control). CAT activity in cell extracts was measured $48 \mathrm{hr}$ after transfection. (A) The enhancer used in each of the CAT reporter constructs is indicated; sequences of the wildtype (G3) and mutated (G3mA, G3mB) G3 enhancers used are shown in Fig. 3A. (B) The reporter construct rInsImC2 carries a mutation in the $\mathrm{C} 2$ site of the rat insulin I pro-
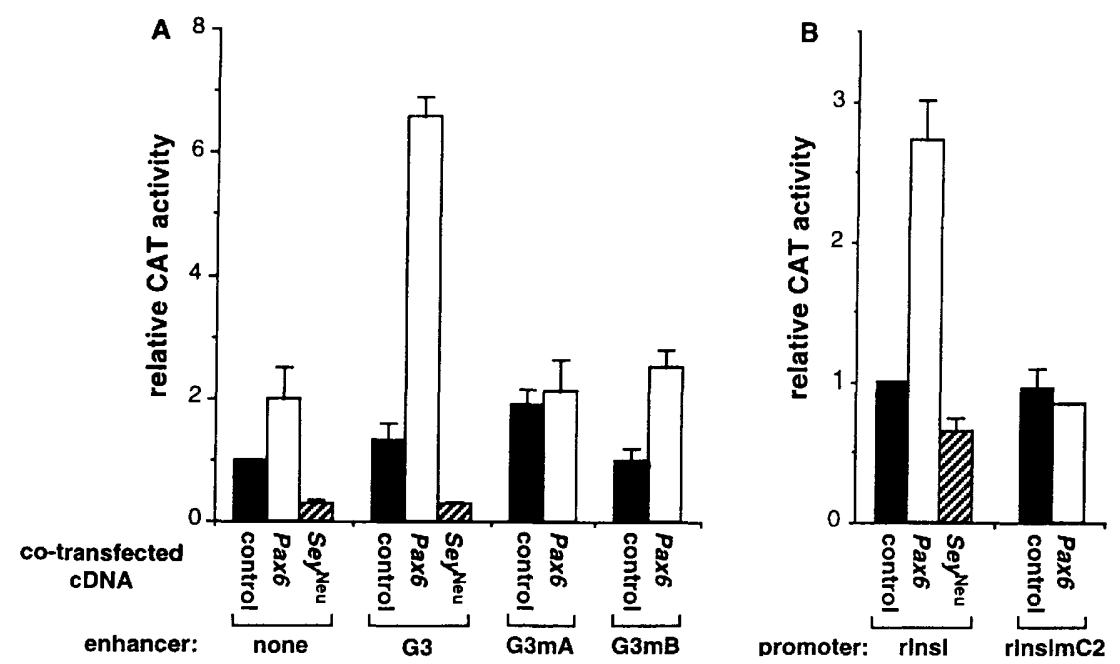
tk-CAT reporter construct $(A)$ or the rInsI promoter $(B)$ was arbitrarily set at 1.0. Each bar shows the average value obtained from four independent transfections. Error bars represent the standard error of the mean. 
seems more likely that a complete set of interacting factors is required for the activation of the hormone genes, and that the remaining factors cannot fully compensate for the loss of Pax 6 function in vivo. The identity of the transcription factors with which PAX6 interacts to activate islet gene promoters remains to be determined. However, it is interesting to note that the results reported here, show that mutation of the G3B site in the context of an intact G3A site decreases the ability of wild-type PAX6 protein to activate transcription of a reporter gene construct. This observation is consistent with the hypothesis that PAX6-binding at the G3A site of the glucagon promoter interacts with a protein that binds at the adjacent G3B site (Knepel et al. 1990). Further analysis in mice carrying mutations in Pax6 and other islet gene transcription factor genes should ultimately lead to an understanding of how interaction among the proteins they encode results in cell type-specific gene expression in the pancreatic islets.

Insulin, which is secreted by $\beta$ cells, inhibits glucagon synthesis and secretion by $\alpha$ cells. This interaction is facilitated by a portal system that directs islet blood flow from the central $\beta$ cells to the peripheral $\alpha$ cells. Interestingly, the inhibitory effect of insulin signaling on the glucagon promoter maps to the A site of the G3 element (Philippe et al. 1995), which we have shown to be the PAX6-binding site. Therefore, insulin signaling may regulate glucagon transcription by modifying PAX6 binding to the glucagon G3 element. The decrease in glucagon transcription in response to insulin is remarkably rapid, and hence probably does not involve regulation of PAX6 de novo synthesis (Philippe 1989). However, because the phosphorylation state of transcription factors can affect their function, it is possible that insulin signaling modifies the phosphorylation state of PAX6, and this in turn affects PAX6 binding to the glucagon G3 element.

\section{The role of PAX6 in pancreatic islet development}

Our finding that the numbers of all four types of endocrine cells are reduced markedly in the pancreas of embryos homozygous for the Sey ${ }^{\mathrm{Neu}}$ mutation indicates that the Pax6 gene has a key role in pancreas development. PAX6 protein is produced in all four types of pancreatic islet cells from the earliest stages of their development, and therefore serves as a marker for the endocrine lineage. The observation that PAX6 protein is detectable as early as E9 in a subset of cells of the primitive gut raises the possibility that the endoderm contains two distinct populations of pancreas precursor cells at that stage; one that is specified to become the exocrine cell population, and the other, marked by Pax6 expression, that will form the endocrine cells. In the latter cell population, Pax6 may have a role in the specification of their fate. Alternatively, Pax 6 might regulate the proliferation of cells that are committed to the pancreatic endocrine cell lineage. This possibility is consistent with data from numerous studies that suggest a role for $\mathrm{Pax}$ genes in the control of cell proliferation. For example,
PAX5 promotes proliferation of lymphocytic B cells in vitro, and during embryogenesis Pax 3 and Pax6 in the spinal cord as well as $P a x 1$ and $P a x 9$ in the endoderm are expressed specifically in mitotically active cells (Goulding et al. 1993; Wakatsuki et al. 1994; Muller et al. 1996). Our finding that the numbers of glucagon- and insulinproducing cells are reduced to approximately the same extent in Sey ${ }^{\mathrm{Neu}}$ mutant homozygotes is consistent with the hypothesis that Pax6 function is required in precursors of the endocrine cell lineage.

Interestingly, a somewhat different conclusion was drawn from a recent study of mice homozygous for a targeted null mutation in the Pax6 gene. The finding that the mutant homozygous pancreas contained few if any $\alpha$ cells and that little or no glucagon was detected led to the suggestion that $\operatorname{Pax} 6$ is required specifically for the differentiation of $\alpha$ cells (St-Onge et al. 1997). However, a $70 \%$ reduction in insulin levels has been observed in the null homozygotes (L. St-Onge and P. Gruss, pers. comm.), although it is not yet known if this correlates with a reduction in the number of $\beta$ cells or if other pancreatic endocrine cell types are affected. It is unclear why the effect we observed on $\alpha$ cells in Sey ${ }^{\mathrm{Neu}}$ mutant embryos is less severe than in the null mutant embryos. One possibility is that $\mathrm{Sey}^{\mathrm{Neu}}$ is a hypomorphic allele that encodes a mutant protein with partial biological activity. Alternatively, genetic background differences may account for the observed differences in phenotype between Sey ${ }^{\mathrm{Neu}}$ and Pax6 null mutants, as there is substantial evidence that $S e{ }^{\mathrm{Neu}}$ is in fact a null allele. First, we and others have provided evidence that the mutant protein is not biochemically active, at least with respect to its ability to stimulate transcription. Glaser et al. (1994) have shown that the truncated carboxy-terminal domain encoded by the $S e y^{\mathrm{Neu}}$ allele, when linked to a GAL-4 DNA-binding domain, fails to transactivate a GAL-4 reporter in a cotransfection assay, whereas the construct containing the wild-type carboxy-terminal domain of PAX6 strongly activates transcription. Likewise, we have found that the protein encoded by the Sey ${ }^{\mathrm{Neu}}$ allele fails to transactivate the insulin and glucagon gene promoters. Second, we were unable to detect PAX6 protein in sections of pancreas from homozygous Sey ${ }^{\mathrm{Neu}}$ embryos. The apparent absence of PAX6 protein might be attributable to instability of the mutant protein in vivo. However, PAX6 protein was detected at low levels in the neural tube of mutant homozygotes (data not shown), possibly because the levels are normally much higher in the neural tube than the pancreas.

In addition to the reduction in number of islet cells, the islets appeared to be disorganized-less clustering of the endocrine cells was observed in the mutant homozygotes than in wild-type and heterozygous embryos. It is possible that normal islet morphogenesis requires a critical number of cells, and that abnormal islet organization is a secondary consequence of the reduction in islet cell number in mutant homozygotes. Alternatively, PAX6 might have a more direct role in islet morphogenesis, perhaps by regulating the expression of genes that mediate cell-cell adhesion. For example, the cell adhe- 
sion molecules NCAM and N-cadherin are expressed in the endocrine and not in the exocrine cells of the pancreas (Moller et al. 1992), and the NCAM promoter is a known target of PAX6 transactivation (Chalepakis et al. 1994). However, we did not detect any significant reduction in the level of NCAM or N-cadherin protein in $\mathrm{Sey}^{\mathrm{Neu}}$ mutant homozygotes (data not shown).

\section{Concluding remarks}

The phenotype of homozygous Sey ${ }^{\mathrm{Neu}}$ mutant embryos demonstrates a requirement for PAX6 in the regulation of the number of islet cells, islet morphology, and the level of islet hormone synthesis. Because the islet hormones, especially insulin and glucagon, have a central role in nutrient metabolism, alterations in the expression or function of PAX6 in the islets could adversely affect nutrient homeostasis in the whole organism. In humans, two forms of heritable diabetes (MODY1 and MODY3) have been attributed recently to autosomal dominant mutations in the transcription factors hepatocyte nuclear factor $1 \alpha$ (HNF $1 \alpha)$ and HNF $4 \alpha$, respectively (Yamagata et al. 1996a,b). As yet, the cause of the decreased insulin secretion in individuals with these mutations is not known; it could be attributable to a decrease in the number of $\beta$ cells, to a decrease in insulin gene expression, or to some other specific defect in $\beta$-cell function. Although it has been shown that HNFl $\alpha$ can transactivate the rat insulin I promoter in vitro (Emens et al. 1992), a direct effect of the autosomal dominant mutations in HNF $1 \alpha$ and HNF $4 \alpha$ on transcription of the insulin gene has not been demonstrated. The most common form of diabetes, type II diabetes, is also a genetic disorder, but results from the contributions of many genes. Our data show that a mutation in one islet transcription factor gene can dramatically reduce insulin production, and raise the possibility that mutations in Pax6 or other genes encoding islet transcription factors might contribute to the inheritance of type II diabetes.

\section{Materials and methods}

Mice

The founder stock of Sey ${ }^{\mathrm{Neu}} /+$ mice used in this study was kindly provided by Brigid Hogan (Vanderbilt University, Nashville, TN). Founder animals were crossed to $\mathrm{CDl}$ mice purchased from Charles River (Wilmington, MA). Mid-day of the day on which the vaginal plug was detected was considered as stage E0.5 in the timing of embryo collection. Embryos were dissected from the decidua at various times of development and staged according to morphological criteria (Kaufman 1992); for embryos at stages before E10.5, somite number was determined. Homozygous (Sey ${ }^{\mathrm{Neu}} / \mathrm{Sey}^{\mathrm{Neu}}$ ), heterozygous $\left(\mathrm{Sey}^{\mathrm{Neu}} /+\right)$ and wild-type littermate embryos were obtained from crosses of heterozygous Sey ${ }^{\mathrm{Neu}}$, selected on the basis of eye size. Heterozygous and wild-type embryos were distinguished by PCR analysis and a restriction enzyme digestion of the amplification product (Hill et al. 1991).

Immunohistochemical and immunofluorescence assays

Pancreata were removed from adult mice and embryos at E15.5 and later stages; pancreatic tissue in embryos at earlier stages was studied in whole embryos. Samples were harvested in PBS and fixed in $4 \%$ paraformaldehyde in PBS overnight, dehydrated, embedded in paraffin (Paraplast), and sectioned at $5 \mu \mathrm{m}$.

Immunohistochemical assays for glucagon, insulin, somatostatin, and PP were performed as described previously with some minor modifications (Naik et al. 1994). The polyclonal antisera employed in these assays were the following: rabbit anti-insulin antibody (Cappel, Durham, NC) diluted 1:600 in $\mathrm{PBS} / 5 \%$ goat serum; guinea pig anti-insulin diluted 1:12000 (Linco, St. Charles, MI); guinea pig anti-glucagon diluted 1:12000 (Linco); rabbit anti-somatostatin (Linco) diluted 1:1000; guinea pig anti-PP (Linco) diluted 1:300; rabbit anti-PAX6-QNR antiserum 11 (kindly provided by Simon Saule, Institut Pasteur, Lille, France), which is directed against the paired domain of quail PAX6 (Turque et al. 1994), diluted 1:4000. Biotinylated goat anti-rabbit IgG and goat anti-guinea pig IgG antibodies (Vector, Burlingame, CA) were used at a 1:200 dilution in PBS/ $5 \%$ goat serum.

For immunofluorescence assays, samples were blocked with goat anti-mouse IgG antibody at a 1:30 dilution and incubated with the primary antibodies at the dilutions described above. For detection of insulin and somatostatin, FITC-conjugated goat anti-rabbit IgG antibody (Cappel) was applied at a 1:100 dilution in $\mathrm{PBS} / 1 \%$ goat serum for $30 \mathrm{~min}$. For detection of glucagon, a rhodamine-conjugated goat anti-guinea pig IgG antibody /Cappel) was used at a 1:300 dilution. Fluorescence was visualized with a Zeiss axioscope.

\section{Quantification of insulin and glucagon concentration and} amylase activity

Protein was extracted from individual pancreata of E18.5 embryos using acid extraction (for insulin and glucagon quantification) or extraction at $\mathrm{pH} 8$ (for measurement of amylase activity), and protein concentration was determined by the Bradford dye-binding assay. The concentrations of insulin and glucagon were determined by radioimmunoassay (RIA) using commercially available kits (Linco). Amylase activity was determined with a colormetric assay (Sigma Diagnostics, St. Louis, MO).

\section{Insulin branched DNA assay}

Total RNA was extracted from whole pancreata of E18.5 embryos using RNAzol (Cinna/Biotecx, Houston, TX) according to the manufacturer's instructions. Mouse insulin II mRNA was quantified with the branched DNA (bDNA) signal amplification system, using $0.25 \mu \mathrm{g}$ of RNA from each pancreas. Briefly, two sets of oligonucleotides were designed to hybridize to the target mRNA. One set links the target mRNA to the assay plate, and the second set links the mRNA to the bDNA amplifiers, which are synthetic DNA oligonucleotides with multiple branches. Each branch then hybridizes to alkaline phosphatase-labeled oligonucleotides that emit light after addition of luminescent substrate. The net result is a marked signal amplification that is proportional to the concentration of the target sequence. Detailed methods for the mouse insulin II mRNA assay have been described (Wang et al. 1997).

\section{Electrophoretic mobility shift assays}

Protein extracts were prepared from $\alpha \mathrm{TC} 1.9, \beta \mathrm{TC} 4$, and NIH3T3 cell lines by the method of Dignam et al. (1983). Electrophoretic mobility shift assays (EMSAs) were performed as described previously, using $5 \%$ nondenaturing polyacrylamide 
gels (German et al. 1992a). Anti-PAX6 antiserum was added to the EMSA reaction mixture at a final dilution of $1: 20$. In the EMSAs in which GST fusion protein was included, 2 ng of protein was added to the EMSA reaction mixture. In vitro transcribed and translated full-length PAX6 protein was obtained with the TNT-coupled reticulocyte lysate system (Promega, Madison, WI) according to supplier's instructions, using SP6 polymerase and the pmPax6 expression vector (kindly provided by Meinrad Busslinger, Institute of Molecular Pathology, Vienna, Austria) as a template (Czerny et al. 1993). One microliter from a $50-\mu l$ total was used for EMSA. EMSAs with competitors were performed using unlabeled oligonucleotides (for sequences, see Fig. 3A) in 50- or 100-fold molar excess.

\section{Production and analysis of PAX4-GST and PAX6-GST fusion proteins}

The GST-fusion proteins used in this study were prepared by cloning sequences encoding the PAX4 and PAX6 paired domains into pGEX-2T (Stratagene, La Jolla, CA), and producing GST fusion proteins by standard methods (Ausubel et al. 1994). The Pax 4 and Pax 6 sequences used in those clones were amplified by PCR from $\beta$ TC 3 cDNA using specific primers from both ends of the coding sequence of the Pax 4 and $P a x 6$ paired domain, respectively. Both clones were sequenced to verify that they encoded PAX4 and PAX6.

Western blotting was performed using standard methods (Ausubel et al. 1994). Briefly, PAX6-GST, PAX4-GST, and GST proteins ( $50 \mathrm{ng}$ each) were fractionated on a $10 \%$ SDS-polyacrylamide gel, then electrophoretically transferred to Immobilon-P membranes (Millipore, Bedford, MA) and probed with antiPAX6 antiserum (1:4000), which was detected with anti-rabbitHRP (1:10000) (Sigma, St. Louis, MO) and ECL reagents (Amersham, Arlington Heights, IL).

\section{Plasmid constructions and transfection assays}

CAT reporter constructs $\mathrm{G} 3, \mathrm{G} 3 \mathrm{~mA}$, and $\mathrm{G} 3 \mathrm{mB}$ oligonucleotides corresponding to -265 to $-231 \mathrm{bp}$ of the rat glucagon promoter were inserted into pFOXCAT2 (Odagiri et al. 1996) between the BamHI and Bg7II sites upstream of a $-109-$ to +51 -bp minimal herpes simplex thymidine kinase promoter (Haltiner et al. 1985). The rInsI and rInsImC2 constructs contained DNA from -345 to $+1 \mathrm{bp}$ of the rat insulin I promoter in pFOXCAT1 (German and Wang 1994). The mutation in rInsImC2 has been described previously as $\mathrm{S} 30$ and covers the bases from -320 to -310 bp (Karlsson et al. 1987).

Pax6 expression constructs Wild-type Pax6 cDNA was isolated from pKW10 and subcloned between the BglII and HindIII sites of the cytomegalovirus (CMV) promoter-driven expression vector pBAT14. pBAT14 is identical to pBAT9 /German et al. 1992a), except for a modification in the polylinker and replacement of the early SV40 polyadenylation signal with the late SV40 polyadenylation signal. To produce a comparable plasmid containing the Sey ${ }^{\mathrm{Neu}}$ allele, an AccI-HindIII fragment of the wild-type cDNA in pBAT14 was replaced with Sey ${ }^{\text {Neu }}$ allele DNA obtained by PCR amplification of homozygous Sey ${ }^{\mathrm{Neu}}$ mouse genomic DNA using 5'-TTCCTATCAGCAGCAGCTTC- $3^{\prime}$ as a $5^{\prime}$ primer, and $5^{\prime}$-CAAGGCAAGAGAAAGCCAAG-3' as a $3^{\prime}$ primer. Both clones were sequenced to verify that they encoded the wild-type and Sey ${ }^{\mathrm{Neu}}$ proteins, respectively.

Transfection assays The Syrian BHK fibroblast line BHK21 was grown and transfected as described previously (German et al. 1992b). Cells were harvested $48 \mathrm{hr}$ later, and CAT assays were performed as described previously using $5 \mu \mathrm{g}$ of the cell protein extract (German et al. 1992b).

\section{Acknowledgments}

We thank Juehu Wang for excellent technical assistance, and our laboratory colleagues for critical readings of the manuscript. This work was supported by National Institutes of Health grants DK41822 to M.S.G. and HD22731 to G.R.M., M.S., A.N., and H.C.E. were recipients of postdoctoral fellowships from the Deutsche Forschungsgemeinschaft, the Human Frontiers Science Program, and the Juvenile Diabetes Foundation International, respectively.

The publication costs of this article were defrayed in part by payment of page charges. This article must therefore be hereby marked "advertisement" in accordance with 18 USC section 1734 solely to indicate this fact.

\section{References}

Ahlgren, U., J. Jonsson, and H. Edlund. 1996. The morphogenesis of the pancreatic mesenchyme is uncoupled from that of the pancreatic epithelium in IPF1/PDX1-deficient mice. Development 122: 1409-1416.

Ahlgren, U., S.L. Pfaff, T.M. Jessell, T. Edlund, and H. Edlund. 1997. Independent requirement for ISL1 in formation of pancreatic mesenchyme and islet cells. Nature 385: 257-260.

Ausubel, F.M., R. Brent, R.E. Kingston, D.D. Moore, J.G. Seidman, J.A. Smith, K. Struhl. 1994. Current protocols in molecular biology (ed. K. Janssen), Greene \& Wiley, New York, NY.

Chalepakis, G., J. Wijnholds, P. Giese, M. Schachner, and P. Gruss. 1994. Characterization of Pax-6 and Hoxa-1 binding to the promoter region of the neural cell adhesion molecule L1. DNA Cell. Biol. 13: 891-900.

Cvekl, A., F. Kashanchi, C.M. Sax, J.N. Brady, and J. Piatigorsky. 1995a. Transcriptional regulation of the mouse alpha A-crystallin gene: Activation dependent on a cyclic AMP-responsive element (DE1/CRE) and a Pax-6-binding site. Mol. Cell. Biol. 15: 653-660.

Cvekl, A., C.M. Sax, X. Li, J.B. McDermott, and J. Piatigorsky. 1995b. Pax-6 and lens-specific transcription of the chicken delta 1-crystallin gene. Proc. Nat1. Acad. Sci. 92: 4681-4685.

Czerny, T., G. Schaffner, and M. Busslinger. 1993. DNA sequence recognition by Pax proteins: Bipartite structure of the paired domain and its binding site. Genes \& Dev. 7: 2048-2061.

Dignam, J.D., R.M. Lebowitz, and R.G. Roeder. 1983. Accurate transcription initiation by RNA Polymerase II in a soluble extract from isolated mammalian nuclei. Nucleic Acids Res. 11: $1475-1489$.

Emens, L.A., D.W. Landers, and L.G. Moss. 1992. Hepatocyte nuclear factor 1 alpha is expressed in a hamster insulinoma line and transactivates the rat insulin I gene. Proc. Natl. Acad. Sci. 89: 7300-7304.

Epstein, J., J. Cai, T. Glaser, L. Jepeal, and R. Maas. 1994. Identification of a Pax paired domain recognition sequence and evidence for DNA-dependent conformational changes. $I$. Biol. Chem. 269: 8355-8361.

German, M.S. and J. Wang. 1994. The insulin gene contains multiple transcriptional elements that respond to glucose. Mol. Cell. Biol. 14: 4067-4075.

German, M.S., L.G. Moss, J. Wang, and W.J. Rutter. 1992a. The insulin and islet amyloid polypeptide genes contain similar cell-specific promoter elements that bind identical $\beta$-cell 
nuclear complexes. Mol. Cell. Biol. 12: 1777-1788.

German, M.S., J. Wang, R.B. Chadwick, and W.J. Rutter. 1992b. Synergistic activation of the insulin gene by a LIM-homeo domain protein and a basic helix-loop-helix protein: Building a functional insulin minienhancer complex. Genes \& Dev. 6: $2165-2176$.

German, M.S., S. Ashcroft, K. Docherty, H. Edlund, T. Edlund, S. Goodison, H. Imura, G. Kennedy, O. Madsen, D. Melloul, L. Moss, K. Olson, A. Permutt, J. Philippe, R.P. Robertson, W.J. Rutter, P. Serup, R. Stein, D. Steiner, M.-J. Tsai, and M.D. Walker. 1995. The insulin promoter: A simplified nomenclature. Diabetes 44: 1002-1004.

Glaser, T., L. Jepeal, J.G. Edwards, S.R. Young, J. Favor, and R.L. Maas. 1994. PAX6 gene dosage effect in a family with congenital cataracts, aniridia, anophthalmia and central nervous system defects [published erratum appears in Nature Genet., 1994 Oct; 8(2): 203]. Nature Genet. 7: 463-471.

Goulding, M.D., A. Lumsden, and P. Gruss. 1993. Signals from the notochord and floor plate regulate the region-specific expression of two Pax genes in the developing spinal cord. Development 117: 1001-1016.

Guz, Y., M.R. Montminy, R. Stein, J. Leonard, L.W. Gamer, C.V. Wright, and G. Teitelman. 1995. Expression of murine STF1 , a putative insulin gene transcription factor, in beta cells of pancreas, duodenal epithelium and pancreatic exocrine and endocrine progenitors during ontogeny. Development 121: $11-18$.

Haltiner, M., T. Kempe, and R. Tjian. 1985. A novel strategy for constructing clustered point mutations. Nucleic Acids Res. 13: $1015-1025$.

Hill, R. and V. Van Heyningen. 1992. Mouse mutations and human disorders are paired. Trends Genet. 8: 119-120.

Hill, R.E., J. Favor, B.L. Hogan, C.C. Ton, G.F. Saunders, I.M. Hanson, J. Prosser, T. Jordan, N.D. Hastie, and V. van Heyningen. 1991. Mouse small eye results from mutations in a paired-like homeobox-containing gene [published erratum appears in Nature 1992, Feb 20; 355(6362): 750). Nature 354: 522-525.

Hogan, B.L., E.M. Hirst, G. Horsburgh, and C.M. Hetherington. 1988. Small eye (Sey): A mouse model for the genetic analysis of craniofacial abnormalities. Development 103(Suppl.) 115-119.

Jensen, J., P. Serup, C. Karlsen, T.F. Nielsen, and O.D. Madsen. 1996. mRNA profiling of rat islet tumors reveals $\mathrm{Nkx} 6.1$ as a beta-cell-specific homeodomain transcription factor. $J$. Biol. Chem. 271: 18749-18758.

Jordan, T., I. Hanson, D. Zaletayev, S. Hodgson, J. Prosser, A. Seawright, N. Hastie, and V. van Heyningen. 1992. The human PAX6 gene is mutated in two patients with aniridia. Nature Genet. 1: 328-332.

Karlsson, O., T. Edlund, J.B. Moss, W.J. Rutter, and M.D. Walker. 1987. A mutational analysis of the insulin gene transcription control region: Expression in beta cells is dependent on two related sequences within the enhancer. Proc. Natl. Acad. Sci. 84: 8819-8823.

Kaufman, M.H. 1992. The atlas of mouse development. Academic Press, San Diego, CA.

Knepel, W., L. Jepeal, and J.F. Habener. 1990. A pancreatic islet cell-specific enhancer-like element in the glucagon gene contains two domains binding distinct cellular proteins. $J$. Biol. Chem. 265: 8725-8735.

Knepel, W., M. Vallejo, J.A. Chafitz, and J.F. Habener. 1991. The pancreatic islet-specific glucagon G3 transcription factors recognize control elements in the rat somatostatin and insulin-I genes. Mol. Endocrinol. 5: 1457-1466.

Kozmik, Z., S. Wang, P. Dorfler, B. Adams, and M. Busslinger.
1992. The promoter of the CD19 gene is a target for the B-cell-specific transcription factor BSAP. Mol. Cell. Biol. 12: 2662-2672.

Leonard, J., B. Peers, T. Johnson, K. Ferreri, S. Lee, and M.R. Montminy. 1993. Characterization of somatostatin transactivating factor-1, a novel homeobox factor that stimulates somatostatin expression in pancreatic islet cells. Mol. Endocrinol. 7: 1275-1283.

Mansouri, A., M. Hallonet, and P. Gruss. 1996. Pax genes and their roles in cell differentiation and development. Curr. Opin. Cell Biol. 8: 851-857.

Matsuo, T., N. Osumi-Yamashita, S. Noji, H. Ohuchi, E. Koyama, F. Myokai, N. Matsuo, S. Taniguchi, H. Doi, S. Iseki et al. 1993. A mutation in the Pax-6 gene in rat small eye is associated with impaired migration of midbrain crest cells. Nature Genet. 3: 299-304.

Miller, C.P., R.E. McGehee, Jr., and J.F. Habener. 1994. IDX-1: A new homeodomain transcription factor expressed in rat pancreatic islets and duodenum that transactivates the somatostatin gene. EMBO J. 13: 1145-1156.

Moller, C.J., S. Christgau, M.R. Williamson, O.D. Madsen, Z.P. Niu, E. Bock, and S. Baekkeskov. 1992. Differential expression of neural cell adhesion molecule and cadherins in pancreatic islets, glucagonomas, and insulinomas. Mol. Endocrinol. 6: 1332-1342.

Muller, T.S., C. Ebensperger, A. Neubuser, H. Koseki, R. Balling, B. Christ, and J. Wilting. 1996. Expression of avian Paxl and $\operatorname{Pax} 9$ is intrinsically regulated in the pharyngeal endoderm, but depends on environmental influences in the paraxial mesoderm. Dev. Biol. 178: 403-417.

Naik, P., G. Christofori, and D. Hanahan. 1994. Insulin-like growth factor II is focally up-regulated and functionally involved as a second signal for oncogene-induced tumorigenesis. Cold Spring Harb. Symp. Quant. Biol. 59: 459-470.

Naya, F.J., C.M. Stellrecht, and M.J. Tsai. 1995. Tissue-specific regulation of the insulin gene by a novel basic helix-loophelix transcription factor. Genes \& Dev. 9: 1009-1019.

Odagiri, H., J. Wang, and M.S. German. 1996. Function of the human insulin promoter in primary cultured islet cells. $J$. Biol. Chem. 271: 1909-1915.

Offield, M.F., T.L. Jetton, P.A. Labosky, M. Ray, R.W. Stein, M.A. Magnuson, B.L. Hogan, and C.V. Wright. 1996. PDX-1 is required for pancreatic outgrowth and differentiation of the rostral duodenum. Development 122: 983-995.

Ohlsson, H., K. Karlsson, and T. Edlund. 1993. IPF1, a homeodomain-containing transactivator of the insulin gene. EMBO $\%$. 12: 4251-4259.

Peers, B., J. Leonard, S. Sharma, G. Teitelman, and M.R. Montminy. 1994. Insulin expression in pancreatic islet cells relies on cooperative interactions between the helix loop helix factor E47 and the homeobox factor STF-1. Mol. Endocrinol. 8: 1798-1806.

Philippe, J. 1989. Glucagon gene transcription is negatively regulated by insulin in a hamster islet cell line. J. Clin. Invest. 84: 672-677.

Philippe, J., C. Morel, and M. Cordier-Bussat. 1995. Islet-specific proteins interact with the insulin-response element of the glucagon gene. I. Biol. Chem. 270: 3039-3045.

Quiring, R., U. Walldorf, U. Kloter, and W.J. Gehring. 1994. Homology of the eyeless gene of Drosophila to the Small eye gene in mice and Aniridia in humans. Science 265: 785-789.

Rudnick, A., T.Y. Ling, H. Odagiri, W.J. Rutter, and M.S. German. 1994. Pancreatic beta cells express a diverse set of homeobox genes. Proc. Nat1. Acad. Sci. 91: 12203-12207.

Sander, M. and M.S. German. 1997. The beta-cell transcription factors and development of the pancreas. J. Mol. Med. 
75: $327-340$.

Schmahl, W., M. Knoedlseder, J. Favor, and D. Davidson. 1993. Defects of neuronal migration and the pathogenesis of cortical malformations are associated with Small eye (Sey) in the mouse, a point mutation at the Pax-6-locus. Acta Neuropathol. 86: 126-135.

Singh, M. and B.K. Birshtein. 1993. NF-HB (BSAP) is a repressor of the murine immunoglobulin heavy-chain $3^{\prime}$ alpha enhancer at early stages of B-cell differentiation. Mol. Cell. Biol. 13: 3611-3622.

Slack, J.M. 1995. Developmental biology of the pancreas. Development 121: 1569-1580.

Sosa-Pineda, B., K. Chowdhury, M. Torres, G. Oliver, and P. Gruss. 1997. The $\mathrm{Pax}_{4}$ gene is essential for differentiation of insulin-producing beta cells in the mammilian pancreas. $\mathrm{Na}$ ture 386: 399-402.

St-Onge, L., B. Sosa-Peneda, K. Chowdhury, A. Mansouri, and P. Gruss. 1997. Pax6 is required for differentiation of glucagonproducing $\alpha$-cells in mouse pancreas. Nature 387: 406-409.

Stoykova, A., R. Fritsch, C. Walther, and P. Gruss. 1996. Forebrain patterning defects in Small eye mutant mice. Development 122: 3453-3465.

Turque, N., S. Plaza, F. Radvanyi, C. Carriere, and S. Saule. 1994. Pax-QNR/Pax-6, a paired box- and homeobox-containing gene expressed in neurons, is also expressed in pancreatic endocrine cells. Mol. Endocrinol. 8: 929-938.

Urbanek, P., Z.Q. Wang, I. Fetka, E.F. Wagner, and M. Busslinger. 1994. Complete block of early B cell differentiation and altered patterning of the posterior midbrain in mice lacking Pax5/BSAP [see Comments]. Cell 79: 901-912.

Wakatsuki, Y., M.F. Neurath, E.E. Max, and W. Strober. 1994. The B cell-specific transcription factor BSAP regulates B cell proliferation. J. Exp. Med. 179: 1099-1108.

Walther, C. and P. Gruss. 1991. Pax-6, a murine paired box gene, is expressed in the developing CNS. Development 113: 1435-1449.

Walther, C., J.L. Guenet, D. Simon, U. Deutsch, B. Jostes, M.D. Goulding, D. Plachov, R. Balling, and P. Gruss. 1991. Pax: A murine multigene family of paired box-containing genes. Genomics 11: 424-434.

Wang, J., L. Shen, H. Najafi, J. Kolberg, F.M. Matschinsky, M. Urdea, and M. German. 1997. Regulation of insulin preRNA splicing by glucose. Proc. Nat1. Acad. Sci. 94: 4360-4365.

Wang, M. and D.J. Drucker. 1995. The LIM domain homeobox gene isl-1 is a positive regulator of islet cell-specific proglucagon gene transcription. J. Biol. Chem. 270: 12646-12652.

White, J.W. and G.F. Saunders. 1986. Structure of the human glucagon gene. Nucleic Acids Res. 14: 4719-4730.

Yamagata, K., H. Furuta, N. Oda, P.J. Kaisaki, S. Menzel, N.J. Cox, S.S. Fajans, S. Signorini, M. Stoffel, and G.I. Bell. 1996a. Mutations in the hepatocyte nuclear factor-4alpha gene in maturity-onset diabetes of the young (MODY1) [see Comments]. Nature 384: 458-460.

Yamagata, K., N. Oda, P.J. Kaisaki, S. Menzel, H. Furuta, M. Vaxillaire, L. Southam, R.D. Cox, G.M. Lathrop, V.V. Boriraj, X. Chen, N.J. Cox, Y. Oda, H. Yano, M.M. Le Beau, S. Yamada, H. Nishigori, J. Takeda, S.S. Fajans, A.T. Hattersley, N. Iwasaki, T. Hansen, O. Pedersen, K.S. Polonsky, G.I. Bell et al. 1996b. Mutations in the hepatocyte nuclear factorlalpha gene in maturity-onset diabetes of the young (MODY3) [see Comment] Nature 384: 455-458.

Zannini, M., H. Francis-Lang, D. Plachov, and R. Di Lauro. 1992. Pax-8, a paired domain-containing protein, binds to a sequence overlapping the recognition site of a homeodomain and activates transcription from two thyroid-specific promoters. Mol. Cell. Biol. 12: 4230-4241. 


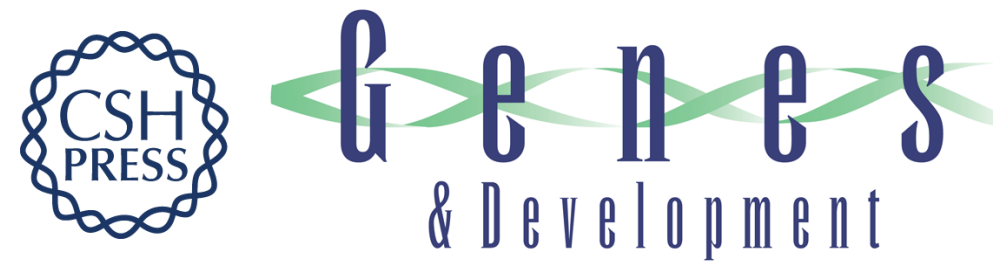

\section{Genetic analysis reveals that PAX6 is required for normal transcription of pancreatic hormone genes and islet development.}

M Sander, A Neubüser, J Kalamaras, et al.

Genes Dev. 1997, 11:

Access the most recent version at doi:10.1101/gad.11.13.1662

References This article cites 60 articles, 32 of which can be accessed free at:

http://genesdev.cshlp.org/content/11/13/1662.full.html\#ref-list-1

License

Email Alerting

Service

Receive free email alerts when new articles cite this article - sign up in the box at the top right corner of the article or click here.

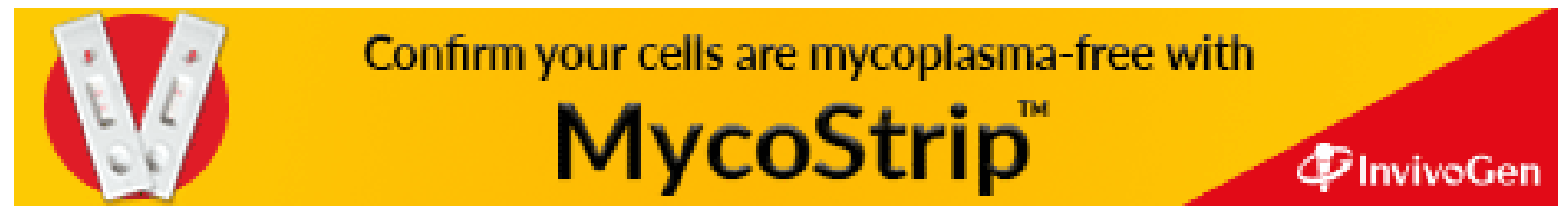

